\title{
MÁRIO DE ANDRADE: A VIAGEM E O VIAJANTE
}

\author{
Gleidys Meyre da Silva Maia
}

RESUMO: The main purpose of this essay is to study the narrative travel and character-traveler's image as discursive strategy of registration, identification and representation of the nation, from the analysis of rhetorical procedures of representation of the other in the rhapsody Macunaima o herói sem nenhum caráter, and in the reports of the ethnographical travel, between May and August 1927, gathered in the work O Turista Aprendiz.

PALAVRAS-CHAVE: narrativa de viagem, representação do outro, alteridade.

Mário de Andrade, em discussão epistolar com Carlos Drummond de Andrade (1924), contrapõe-se ao dilema crítico que opõe nacionalismo e universalismo, onde o primeiro convém às massas e o segundo às elites. $\mathrm{O}$ dilema que aflige Drummond é desfeito por uma concepção pragmática de nacionalismo de Mário de Andrade: "Nacionalismo quer simplesmente dizer: ser nacional (...) Nada de dizer: se um dia eu for nacional, serei nacional (...) Você faça um esforcinho pra abrasileirar-se". O título deste trabalho toma de empréstimo, não somente o dilema crítico, mas, principalmente a concepção de nacionalismo proposta por Mário de Andrade: "Ninguém que seja verda-

Gleidys Meyre da Silva Maia é professora de Literatura Brasileira na FACOS de Osório e Mestranda em Literatura Brasileira na UFRGS. 
deiramente, isto é, viva, se relacione com o seu passado, com as suas necessidades espirituais, se relacione com o meio e com a terra, com a família, etc., ninguém que seja verdadeiramente, deixará de ser nacional" (ANDRADE, 1982, p. 57).

A nação é uma das categorias que organizam a história e a vida dos povos, mas sua configuração é datada. Começa na era moderna, junto com a formação dos Estados, chamados, a partir de então, Estados-Nacionais. A Nação é, como na feliz expressão de Benedict Anderson, uma "comunidade imaginada". Pessoas oriundas de diversos lugares, tendo ou não religião comum, pertencendo ou não a diferentes etnias passam a se sentir identificadas com um território e/ou com um Estado.

A homogeneidade do povo de cada país é construída. O sentido de pertencimento, a identificação se produz mediante mecanismos, processos que permitem uma atitude de familiaridade diante de uma imagem representada. Esta familiaridade real ou inventada afasta a atitude de manter-se estrangeiro. As coisas novas precisam estar relacionadas à experiência anterior para que sejam aceitas como fatos verdadeiros. A veracidade se obtém pela associação do novo com imagens já existentes no arquivo da experiência.

O processo de identificação liga experiências novas a experiências antigas, produz familiaridade e/ou estranhamentos e distinções por meio da linguagem oral, escrita, visual. Assim, as identificações são dominadas pela semelhança versus diferença, e pela igualdade versus hierarquia. A nação é uma das formas de construção de identidade, como o lugar de origem, a família, a religião, a etnia.

O século XIX oferece exemplos ricos e diferenciados deste processo de identidades correlacionadas à construção dos Estados Nacionais. A história e a geografia se desenvolvem e têm papel relevante na tarefa de produção de conhecimento. A literatura transformou este conhecimento em reconhecimento (HOBSBOWM, 1991, p. 19). A criação do Instituto Histórico e Geográfico Brasileiro, em 1838, e a literatura romântica, com o indianismo em meados do século, preencheram este duplo papel na construção da identidade nacional.

A questão do nacional no Brasil tem assumido um desenho que a define como um problema. No confronto com a Europa, e mais tarde com os Estados Unidos, estamos sempre às voltas com o que nos falta. A avaliação negativa do passado e das possibilidades futuras é constante. $\mathrm{O}$ confronto do Brasil com outros países produz um leque de diferenças, aponta as singularidades que passam a ser avaliadas positiva ou negativamente.

Uma dessas avaliações se dá sob o impacto da Primeira Guerra Mundial. Se a Europa está decadente, o futuro estará na América. Daí ser necessá- 
rio repensar o Brasil marcado pelo atraso econômico, pelo clima e pela raça. Esses fatores eram pensados como negativos porque a elite se via e pensava o país com mentalidade européia. Era preciso quebrar este constrangimento externo e voltar-se para as raízes brasileiras. Era preciso inventar a autenticidade - buscar raízes nacionais em um passado histórico ou imemorial (mitos). O mito da pureza cultural se acopla ao espírito do povo, o popular passa a ser o locus da autenticidade. O modernismo cria e difunde a necessidade de identificar a substância do SER brasileiro, denuncia os conhecimentos/saberes atrasados que impedem a captação do ser brasileiro e colabora na elaboração de inúmeros "retratos do Brasil".

Desde o Manifesto Pau-Brasil, de Oswald de Andrade, os modernistas pretendiam criar uma arte e uma literatura modernas no Brasil sem simplesmente imitar os movimentos da vanguarda européia, em busca de uma arte "autenticamente nacional". Mas como renovar, ser moderno, ser autêntico sem copiar seus invejados modelos europeus? Esse impasse faz com que o rumo do movimento no Brasil se desloque paulatinamente para o tema do nacional. A necessidade de re-criar a nação, buscar a identidade nacional e instaurar uma nova ordem, tanto cultural quanto econômica faz com que esses missionários retomem o passado e dediquem-se à pesquisa de signos e materiais de representação de uma brasilidade original e autêntica. Esse é o esforço a que se referia Mário de Andrade na carta ao poeta Carlos Drummond.

Os modernistas, a exemplo de Mário de Andrade, embrenham-se pelo interior do país, recolhem material, uma verdadeira ação etnográfica, e realizam obras onde o tema do nacional está intrinsecamente ligado às viagens, às descobertas e à atualização cultural. Ver o Brasil através das lentes modernistas significa descobrir o país e a realidade nacional a partir do tempo presente. Em 1927, Mário de Andrade realiza a primeira viagem etnográfica ao Norte do país, cujo relato do cronista e ficcionista está reunido na obra $O$ Turista Aprendiz. A partir dessa viagem, o viajante Mário de Andrade, o turista aprendiz, será surpreendido pelo signo da diferença e da diversidade, alterando sua concepção de nacionalismo. Não basta se esforçar para ser nacional, o nacional surge tão maior e tão extraordinário que cede lugar para o estranhamento, para a perplexidade.

Não sei, quero resumir minhas impressões desta viagem litorânea por nordeste e norte do Brasil, não consigo bem, estou um bocado aturdido, maravilhado, mas não sei... Há uma espécie de sensação ficada da insuficiência, de sarapintação, que me estraga todo o europeu cinzento e bem arranjadinho que ainda tenho dentro de mim. (ANDRADE, 1983, 18/ 05/27)

Essa perplexidade já se revelara para Mário de Andrade durante a histórica "Viagem da Descoberta do Brasil", realizada em 1924, Semana Santa dos modernistas e seus amigos, acompanhando o artista suíço Blaise Cendrars. 
Detendo-se em povoações e cidades históricas mineiras, para os modernistas tudo parecia novo e, ao mesmo tempo, muito antigo. A atitude paradoxal tem uma lógica. O distanciamento que a maior parte de nossos escritores manteve com a realidade brasileira fazia com que a paisagem da Minas barroca surgisse aos olhos dos modernistas como qualquer coisa de novo e original, dentro, portanto, do quadro de autenticidade cultural que eles procuravam.

A reflexão dos modernistas, vinda desse contato que se pretendeu direto com uma parcela do povo brasileiro, pôde focalizar os processos de criação popular percebendo-os mais livres e mais condizentes com nossas condições e, em alguns pontos, até mesmo apresentando coincidência com propostas de determinadas vanguardas européias. A "Viagem da Descoberta do Brasil" provoca um amadurecimento no projeto nacionalista dos modernistas, fazendo com que a ênfase, que de início recaía com mais força sobre o estético, possa ir, progressivamente, abrangendo e sulcando o projeto ideológico.

Ao longo de suas leituras de obras de folclore, Mário de Andrade irá entendendo o Norte e o Nordeste como ricos depositórios de tradição e cultura popular, que anseia conhecer diretamente.

\section{O TURISTA APRENDIZ E A RETÓRICA DA ALTERIDADE}

Creio que vou pro norte mês que vem, numa bonitíssima viagem. Dona Olívia faz tempo que vinha planejando uma viagem pelo Amazonas a dentro. E insistia sempre comigo para que fosse no grupo. Eu ia resistindo, resistindo e amolecendo também. (BANDEIRA, s/d., p. 161)

AAmazônia é uma antiga atração, sendo valorizada por Mário desde os seus primeiros escritos e naquele momento, sobretudo, estando Macunaíma ainda em fase de redação, como a sede de uma vivência tropical. O contato com a cultura popular levou-o, nos anos seguintes, a uma pesquisa intensa da literatura popular e de etnografia do Brasil. Nessa pesquisa, encontra o anti-herói Macunaíma no lendário indígena recolhido por Koch-Gruenberg em Von Roraima zum Orinoco; passa a reunir material para a rapsódia que redigirá nas férias de fim de ano, na chacra do tio Pio, em 1926. Macunaíma o herói sem nenhum caráter tem sua primeira versão em trabalho ininterrupto de uma semana.

Entre maio e agosto de 1927, Mário de Andrade, em companhia de D. Olívia Guedes Penteado e uma sobrinha, Margarida Guedes Nogueira, além de Dulce do Amaral Pinto, realiza a primeira viagem etnográfica ao Norte, percorrendo parte da Amazônia e chegando a Iquitos, no Peru, única ausência sua do Brasil. Da viagem resultará o diário O Turista Aprendiz ( $1^{a}$ Parte) e o intercâmbio com modernistas do nordeste e do norte. 
Não fui feito pra viajar, bolas! Estou sorrindo, mas por dentro de mim vai um arrependimento assombrado, cor de incesto. Entro na cabina, agora é tarde, já parti, nem posso me arrepender. Um vazio compacto dentro de mim. Sento em mim. (ANDRADE, 1983, 07/05/27)

O homem urbano Mário de Andrade sente-se às avessas com a idéia do novo, do desconhecido, incomodado com a distância da rotina, um antiviajante (Cf. MAYA, 1999, p. 74-5.), cuja antiviagem seria o acúmulo de informações, a visão elitista da cultura brasileira, que vai se dissolvendo a medida em que o escritor toma contato com o real. O desconforto, o incômodo da viagem rumo ao desconhecido é ressaltado na medida em que o habitual, o costumeiro, o cotidiano são substituídos pela novidade, pelo exótico, pelo diferente. Essas substituições são elaboradas e acompanhadas pela sensação paradoxal de estar sempre de "fora" dos acontecimentos e, ao mesmo tempo, a necessidade de se integrar e participar desses acontecimentos.

Fui provar minhas roupas de linho, deixarei aqui no hotel todas as roupas que trouxe de S. Paulo, arre! De-noite, baile do "Assembléia" em honra dos viajantes. Não fui. É incrível como vivo excitado, se vê que ainda não sei viajar, gozo demais, concordo demais, não saboreio bem a minha vida (...) (ANDRADE, 1983, 21/05/27)

A viagem não é lazer, mas aprendizado dolorido, sofrido, atravessamento da zona fronteiriça entre o imaginário e o real, popular e erudito e marca o percurso descentrado de saída de seus próprios limites intelectuais para incorporar elementos considerados à margem da cultura oficial. A bordo do barco São Salvador, o viajante se sente ridículo ao experimentar pela primeira vez uma indumentária diferente, comportamento que expressa a separação entre dois mundos: o conhecido e o desconhecido. A recusa em ir ao baile é, na verdade, a recusa em ultrapassar os limites, a zona fronteiriça do mundo a ser descoberto. Não saber viajar significa não saber se adequar à multiplicidade, não saber trabalhar o diferente, o Outro.

Mas o que carece mesmo exaltar nestas índias das classes inferiores da Amazônia, é a elegância discreta embora desenvolta com que elas sabem ficar nuas, que diferença das mulheres civilizadas! (...)... ficam nuas mas tomam um ar de saia-e-blusa completamente caipira e abobalhado. É horrível. Nunca vi uma burguesa minha contemporânea que não tomasse ar de saia-e-blusa ao se despir. (ANDRADE, 1983, 04/06/27)

Mário de Andrade assume o olhar e a atitude do cronista de costumes, deixa-se levar pela diferença propondo uma leitura referencial de elementos daquele mundo tão surpreendente: como um estrangeiro, o viajante narra o mundo a partir do universo já conhecido, procura compreender o outro através de um enquadramento referencial. Compara a beleza e a 
graciosidade da nudez das índias com a nudez convencional, pré-determinada das mulheres civilizadas. Esse procedimento retórico é um dos mais comuns da literatura de viagem e esse tema específico já havia sido explorado por outro viajante. Pero Vaz de Caminha, o escrivão da frota de Pedro Álvares Cabral realiza o mesmo procedimento e recorre às mesmas imagens na comparação entre índias e mulheres civilizadas. Se por um lado podemos elaborar uma leitura do percurso da estereotipia entre os dois viajantes, por outro lado, podemos trabalhar o texto marioandradino como uma paródia do texto de Caminha. O título bem humorado, dado por ele ao relato de viagem - O turista aprendiz: Viagens pelo Amazonas até o Peru, pelo Madeira até a Bolivia e por Marajó até dizer chega - é condizente com o caráter ficcional e dessacralizador, pois também é uma paródia dos títulos longos dos cronistas e dos viajantes.

Creio que índios tiveram medo da gente, lenha trouxeram quanta precisávamos, porém não houve jeito de subirem a bordo pra mostrarmos a eles a galinha trazida só pra isso. Então desistimos e o vaticano andou. (ANDRADE, 1983, 28/05/27)

Neste trecho do relato fica explícita a referência a um dos episódios mais conhecidos da Carta de Pero Vaz de Caminha, onde os índios ficam ao mesmo tempo apavorados e admirados com uma galinha, animal desconhecido até então para eles. $\mathrm{O}$ tom satírico com que Mário de Andrade narra o medo que os indígenas têm no encontro com gentes desconhecidas está vinculado diretamente à imagem da galinha trazida só pra isso. A sátira provoca um desequilíbrio entre a matéria literária do texto de Caminha e o relato de viagem do escritor. Nesse sentido, não podemos fazer uma leitura do texto marioandradino somente dentro do processo de estereotipia das narrativas de viagens, sem considerar o conhecimento intelectual do modernista e seu projeto estético. Mário de Andrade utiliza o discurso alheio, conhecido e institucionalizado, como um instrumento de opacidade da visão do viajante em terra estranha, na impossibilidade de compreender o que é visto e sentido.

Creio que por causa do calor os índios desta região são mui barbudos e trazem a barba a tiracolo, em tranças de desenhos complicadíssimos. E é costume os jacarés aparecerem sempre a primeiro de junho nos igapós de beira-rio, pra os turistas poderem contemplá-los com satisfação. Enxergamos muitos boiando. (ANDRADE, 1983, 01/06/27)

A impossibilidade de compreender o mundo novo na sua totalidade, também, cede lugar à invenção, à explicação inverossímil dos fatos e acontecimentos. $\mathrm{O}$ viajante não consegue compreender como, em um dia de calor tão intenso que até é possível ver a barba crescer com a ajuda de uma lente de aumento, os índios não possuem pêlos pelo corpo. A conclusão é que eles devem trazer a barba escondida. Da mesma forma, a imagem 
dos jacarés boiando para tomarem banho de sol recebe uma explicação conveniente aos desejos do olhar do turista em apreciá-los. Aqui, novamente, há uma quebra dos procedimentos da narrativa de viagem, uma vez que não há compromisso algum com a veracidade dos fatos.

A estranheza diante do já conhecido promove o deslocamento do real para o cenário do imaginário, onde o viajante pode estabelecer novos paradigmas para a composição do texto. O humor é o recurso de que mais se serve o viajante para estabelecer o insólito, o estranho na representação do outro e para quebrar a linearidade do olhar nessa mesma representação. Esse deslocamento gera um descompasso, uma dissonância que se realiza na imagem alegórica dos acontecimentos. No entanto, o viajante não consegue se desvencilhar o tempo todo do compromisso com a verdade: "Nestes 'apontamentos de viagem' como dizia meu avô Leite Morais, às vezes paro hesitando em contar certas coisas, com medo que não me acreditem". (ANDRADE, 1983, 27/05/27)

A preocupação do viajante em dar veracidade aos acontecimentos vistos é colocada em contraste com as invenções e explicações inverossímeis destes mesmos acontecimentos. A grandiosidade da região e seus predicados exuberantes e exagerados colaboram para o discurso criativo e inventado da realidade. A fascinação do viajante ante essa exacerbação da natureza provoca a linguagem e a atitude do thôma e a necessidade em descrever e explicar tudo que vê, através do quê o escritor dá asas à imaginação e à criatividade.

No Amazonas não cortam rabo de cachorro, pra ele poder se equilibrar em cima da estiva. Estiva: em geral um açaizeiro derrubado, servindo de pontão no porto. No que por aqui chamam de "porto", às vezes apenas um abertinho no mato e uma descida de terra mais lisa, se dissolvendo na água barrenta do rio. (ANDRADE, 1983, 30/05/27)

A necessidade didática e educativa na descrição de fatos e acontecimentos aproxima-se muito da postura do narrador com um olhar armado, interessado, em sintonia com uma literatura marcada por um compromisso ilustrado e pela necessidade imperiosa de afirmar uma "essência original da nacionalidade" (Cf. SUSSEKIND, 1990, p. 127). Esse olhar armado do viajante, muitas vezes, entra em conflito com o olhar do escritor e não subsiste aos processos de inventividade na descrição das paisagens, dos costumes. $\mathrm{O}$ olhar é seduzido pelo objeto, pois o narrador sobrepõe ao objeto visto, outros elementos díspares, oriundos de lugares díspares.

Segundo François Hartog (1999, p. 260), essa postura do narradorviajante compõe um dos aspectos específicos da retórica da alteridade, onde a representação do outro se constrói pelo processo da tradução, isto é, visa transportar o outro ao mesmo. Nessa operação, o momento mais 
importante é o da nomeação, onde a tradução opera no sentido de versão. As descrições e nomeações feitas por Mário de Andrade fazem ver e fazer ver promove um saber.

Pelo anúncio da tarde, chegamos a Santarém, com estranhas sensações venezianas, por causa do hotel ancorado no porto, enfiando o paredão n'água, e com janelas de ogiva! Os venezianos falam muito bem a nossa língua e são todos de uma cor tapuia escura, mui lisa. Fomos recebidos com muita cordialidade pelo doge que nos mostrou a cidade que acaba de-repente. (ANDRADE, 1983, 31/05/27)

Madrugada sublime na tolda do vaticano. Manhãzinha paramos para cortar canarana pros bois. Um casal de araras atravessa o rio. Bandos de borboletas amarelas na pele do rio. Derepente uma azul, das grandes. Libélulas em quantidade. E os peixes sobressaltando nos remansos. (ANDRADE, 1983, 16/ $06 / 27)$

A inversão na descrição dos habitantes de Santarém e o tom lírico na descrição da cena matinal são exemplos do consórcio entre o pragmatismo a que se propõe o viajante e a discursividade literária do escritor-poeta. O relato inteiro está permeado por esse olhar pendular e, Mário de Andrade, pela reiteração desse procedimento, assume a sua condição de turista aprendiz, cujo conhecimento intelectual é constantemente colocado em cheque pelo deslocamento entre real e imaginário.

Mário, modernista e também nacionalista, fará ficção a partir da própria realidade experimentada ou observada, fazendo questão de explorá-la em dois aspectos: o real e o ficcional, partindo desse mesmo real. Nesse sentido, é muito auxiliado por uma concepção de realidade sul-americana, uma vez que, instrumentalizado pelo senso crítico, onsegue entender que, dentro de uma ótica européia, marcada pelo racionalismo, nossa realidade seria o maravilhoso laborado em sua peculiaridade, sensível a uma abordagem desmistificadora, que procura denunciar a impropriedade dessa mesma ótica.

Para Mário de Andrade há muito que conhecer, que visitar, mas, acabaram-se as terras por descobrir, por desvendar ao nível de um real geograficamente quase esgotado pela descrição e pela fotografia (LOPEZ, 1983, p. 40). A função do cronista medieval ou de nossa colonização continua existindo para Mário, quando o captamos lidando com a informação: sua experiência, paisagens, formas de trabalho nas regiões visitadas, população, cidades e arquitetura, encontro com personalidades, passeios, episódios e companheiros de viagem. O cronista do século XX seria incorporar o Brasil, criticamente, à sua vivência.

Mário de Andrade enquanto prosador aparece-nos então como um moderno, na medida em que se debruça sobre seus recursos de expressão e tenta captar criticamente o momento em vive. $O$ insólito, o estranho, quer ao 
nível da realidade em um mundo hiperbólico, mítico ou contraditório, quer no nível do ficcional puro, exibido através do humor, será característica da obra.

Macunaíma ainda não havia chegado a sua versão definitiva e seus elementos são uma presença constante no espírito do escritor.

uma dançarina pacaá, que numa espécie de cabaré erguido por ela mesma a légua e meia do mocambo, anunciara espetáculos de nu artístico, aparecendo inteiramente vestida mas com a boca à mostra, e cantando cançonetas napolitanas que aprendera com um regatão peruano que lhe tirara a orelha.(ANDRADE, 1983, 08/06/27)

Neste trecho é o regatão peruano que no romance será Venceslau Pietro Pietra, e a expressão popular "légua e meia" de uso constante naquele texto, conforme assinala Proença (Cf. PROENÇA, 1969, p. 138140). Por outro lado, Mário de Andrade incorpora ao romance elementos regionais e pessoas encontradas nessa viagem ao norte do Brasil, como é o caso das Irmãs Louro Vieira, donas de uma farmácia em Óbidos e extraordinárias fabricantes de doces em forma de flores e frutos. Na descrição do palácio do gigante Piaimã ocorre o segundo ponto de conjunção entre a ficção e a realidade, através de aproveitamentos recolhidos na viagem ao Norte do país, relatados em $O$ Turista Aprendiz. A alcova do palácio do comedor de gente é decorada no centro com uma mesa de jacarandá esculpido "arranjada com louça branco-encarnada de Breves e cerâmica de Belém”.

O importante é atentarmos para o fato de que a viagem do escritor ao Norte do país significa, não só a saciedade da aventura, da descoberta do já conhecido, mas, principalmente, a pesquisa e o recolhimento de elementos que mais tarde serão aproveitados como matéria literária, cuja significação episódica subleva-se à representação do nacional numa obra como Macunaíma.

\section{MACUNAÍMA, OU A SENSAÇÃO DE NÃO ESTAR DE TODO.}

Roberto Schwarz, no ensaio A importação do romance e suas contradições em Alencar, elabora a filiação de Macunaíma ao romance de Alencar, isto é, à tradição das narrativas do início do século XIX: "De Iracema, alguma coisa veio até Macunaíma: as andanças que entrelaçam aventuras, o corpo geográfico do país, a matéria mitológica, a toponímia índia e a História branca..." $(1988$, p. 31$)$.

A partir do excelente trabalho de M. Cavalcanti Proença-Roteiro de Macunaima- a crítica brasileira trabalha a rapsódia de Mário de Andrade sob o signo da viagem e compreende o herói sem nenhum caráter como persona- 
gem-viajante. Essa também é uma compreensão nossa, com a diferença de que a viagem e o viajante serão trabalhos nessa análise a partir dos movimentos e deslocamentos que traduzam o roteiro da viagem e do viajante dentro do projeto modernista de "invenção" da nação e da nacionalidade. O herói sem nenhum caráter percorre um largo espaço do território nacional, saindo do fundo do mato virgem, do mundo primitivo, original, rumo à civilização num movimento avesso ao movimento dos cronistas e narradores das narrativas de viagem do período colonial, ou mesmo das narrativas medievais. Esse mundo às avessas promove de imediato a estranheza, o insólito diante do mundo a ser desvendado, fazendo com que o herói passe por um processo surrealista de composição. Tal processo libera o personagem-viajante do compromisso com a verdade dos fatos, de um “olhar armado", e o joga no imaginário da nacionalidade ou do desejo da totalidade da nação.

Nesse sentido, podemos elaborar correlações e justaposições entre a viagem macunaímica e a viagem do turista aprendiz, onde o personagem-viajante e o escritor- viajante são dominados pelo signo da diferença, da diversidade, da perplexidade de mundos des-conhecidos, mas já sabidos, levando sempre em consideração o avesso do roteiro de ambos. Esse deslocamento entre imaginário e real, entre dentro e fora, entre verdade e ficção é próprio de determinados narradores de viagem, destacados por Flora Süssekind por uma sensação de não estar de todo (1990, p. 20-21). O esforço de abrasileirar-se em um e a composição da totalidade do "brasileiro" em outro se caracterizam pelo excesso de inventividade nesse descompasso entre real e imaginário.

Devemos considerar também que, mesmo Macunaíma já estar escrito na sua primeira versão, a viagem do escritor-viajante influencia sobremaneira a composição da viagem macunaímica pela proximidade temporal em que as duas acontecem e pela mesma autoria. Macunaíma, portanto, é preenchido pelo signo da viagem que ora se aproxima de O Turista Aprendiz, ora se afasta do sentido desse relato, para aderir a outras viagens, sejam literárias ou não. Interessa-nos identificar e destacar esses sentidos da viagem como linguagem e instrumento estético de narrar a nação.

As andanças do "herói" apresentam três movimentos principais:

1- a viagem de formação- do capítulo I Macunaíma ao III Ci, Mãe do Mato;

2- $\quad$ a viagem de transformação - do IV- Boiúna Luna ao XIV- Muiraquitã;

3- a viagem às origens - do XV - A pacuera de Oibê ao Epílogo;

\section{1 - A viagem de formação}

Esse movimento pode ser analisado a partir de dois movimentos. O primeiro caracteriza-se como um ritual de passagem onde o heró $i$ tem 
de passar por vários obstáculos para sair da infância e entrar no mundo adulto. Um desses obstáculos é o deslocamento físico para terras desconhecidas, onde a solidão e desamparo fazem com que o personagem ganhe experiência de vida, autonomia de ação, sem depender de pessoas próximas para sobrevier.

Para melhor compreensão de como ocorrem esses movimentos, empreenderemos sempre uma análise dos elementos textuais. O nascimento do "herói", suas primeiras aventuras amorosas, suas características principais (preguiça, malandragem, proximidade com o sobrenatural, vingativo, etc.) são mostrados no primeiro capítulo, uma forma de apresentação do mundo que envolverá a narrativa.

No segundo capítulo, a formação do herói caracteriza-se primeiramente pelo ritual de passagem da infância para idade adulta através de seu isolamento da tribo, do afastamento do mundo organizado: a mãe tapanhuma o leva para o fim do mundo - Cafundó do Judas - para não crescer mais. A viagem configura-se como uma punição, uma espécie de formação às avessas que resulta no seu contrário.

Carregou o herói na cintura e partiu. Atravessou o mato e chegou no capoeirão chamado Cafundó do Judas. Andou légua e meia nele, nem se enxergava mato mais, era um coberto plano apenas movimentado com o pulinho dos cajueiros. Nem guaxe animava a solidão. A velha botou o curumim no campo onde ele podia crescer mais não e falou:

- Agora vossa mãe vai embora. Tu ficas perdido no coberto e podes crescer mais não. (ANDRADE, 1988, p. 17).

A punição se constitui na perdição do herói, isto é, o enfrentamento com o desconhecido, a separação do mundo sabido, a inserção do herói em um mundo dominado pelo isolamento, pela despovoação, pela ausência de familiaridade com a cultura, a língua conhecida e usada. A ausência desses elementos implicaria no não crescimento do herói, sua não formação como sujeito autônomo e livre.

O encontro com o Currupira é de extrema importância para neutralizar a punição e reverter a condição do herói. Ao contar a causa do castigo, o Currupira, ente lendário e sobrenatural, guardião das florestas, considera que a ação do herói não exemplifica mais uma ação infantil, mas uma ação adulta. Note-se, aqui, que também o Currupira está deslocado do seu lugar de origem, uma forma de desenraização cultural análoga a do herói. A análise feita pelo Currupira das ações do herói é ratificada pela cotia, que, através de uma poção mágica, transforma o corpo do herói em corpo de homem.

O herói deu um espirro e botou corpo. Foi desempenando crescendo fortificando e ficou do tamanho dum homem taludo. Porém a cabeça não molhada ficou pra sempre rombuda e com carinha enjoativa de piá. (ANDRADE, 1988, p. 19). 
A punição dada pela mãe tapanhuma é desrealizada pelas ações do herói, resultando em seu conhecimento de seres antes desconhecidos e em seu crescimento físico, isto é, em uma transformação que é ao mesmo tempo uma confirmação daquilo que ele já era, do que já existia. $\mathrm{O}$ isolamento da comunidade em lugar desconhecido para fins de passagem de uma idade a outra não é uma novidade na cultura ocidental. Basta lembrarmos dos efebos na sociedade grega, cuja ritual de passagem para a maioridade consistia no isolamento fora dos limites da cidade como atesta Jean-Pierre Vernant (1988, p. 47).

Realizado o ritual, volta para a tribo e vinga-se da mãe matando-a ${ }^{1}$. A transgressão tem como resultado a falta de referência, a perda da liderança, o que faz com que todos saiam à procura de outra referência. Isso implica em um segundo movimento da viagem de formação. Essas primeiras viagens já apresentam uma das principais características do deslocamento físico: a desgeograficalização - por ser detentor de poderes próprio de um semideus, o herói se desloca por distâncias máximas, pólos distanciados, cuja economia temporal percebe-se pelo tempo da narrativa. Essa característica será uma constante nas viagens-fugas, nas viagens-passeios, etc.

$\mathrm{O}$ segundo movimento inicia com a viagem ao encontro de $\mathrm{Ci}$, Mãe do Mato - para esse encontro com a mulher guerreira, é necessário primeiro suprimir o elemento feminino da comitiva de viagem - Iriqui, a companheira do herói. A bela Iriqui é deixada no tronco de uma samaúma. Encontram a icamiaba dormindo e o herói joga-se sobre ela para "brincar". O sexo sempre foi um dos elementos de dominação feminina na sociedade ocidental. Sem ter como lutar contra três, a guerreira icamiaba é dominada e o herói, após o sexo, transformase em Imperador do Mato-Virgem. O resultado do encontro do herói com a icamiaba serão o casamento e a ascensão social - uma configuração às avessas da tradição ocidental. Para chegar ao império de $\mathrm{Ci}$, os viajantes, Macunaíma, Jiguê e Maanape passam por vários lugares até chegar aos cerros da Venezuela. A vitória sobre a icamiaba é uma vergonha para um guerreiro, mas não para Macunaíma, que com o casamento e a ascensão social completa a viagem de formação. Agora ele é um homem, pode-se dizer, com o ethos elevado.

O herói vivia sossegado. Passava os dias marupiara na rede matando formigas taiocas, chupitando golinhos estalados de pajuari e quando agarrava cantando acompanhado pelos sons gotejantes do cotcho, os matos reboavam com doçura adormecendo as cobras os carrapatos os mosquitos as formigas e os deuses ruins. (ANDRADE, 1988, p. 23)

${ }^{1}$ No túmulo da mãe, Maanape, irmão catimbozeiro do herói, inscreve um epitáfio que, segundo Telê Porto Ancona Lopes, valoriza a arte indígena ligada à magia e ao passado arqueológico brasileiro, recapturando, no desenho central, inscrição às margens do rio Japurá, no Pará, exibida por Debret na Voyage pittoresque et historique au Brésil, prancha 30 "Scultupture em creux". 
Esse movimento leva o "herói” à Idade do Ouro - felicidade, sossego, prestígio, o nascimento do filho, etc. Para festejar o nascimento do filho são trazidos, dos mais diversos locais do país, muitos presentes. Na listagem dos presentes observamos o primeiro contato direto entre a escritura da rapsódia e o relato de $O$ Turista Aprendiz. Filtravam o milhor tamarindo das irmãs Louro Vieira, de Óbidos, pro menino engulir no refresco o remedinho pra lombriga. (ANDRADE, 1988, p. 27)

A citação de nomes e lugares identificados historicamente estabelece um consórcio entre o real e o imaginário, num deslocamento espacio-temporal que colaboram para dar veracidade e crédito ao conhecimento do narrador. Podemos dizer que, nesses casos, o processo de autoria se sobrepõe ao estatuto do narrador e funde a narração da realidade e a narração da ficção.

A morte do filho e da companheira provoca uma ruptura na condição do herói e é o motivo da elaboração da segunda viagem - a companheira antes de se transformar em Beta do Centauro, dá ao herói o talismã - a muiraquitã, amuleto de proteção e referência de suas origens.

\section{2- Viagem de Transformação}

Macunaíma perdeu o filho e a companheira, mas não perdeu a posição social, continuava Imperador do Mato Virgem, pois essa condição é o atestado de sua completa formação. Os três irmãos saem sem rumo mundo afora, sem um objetivo específico, sem uma referência que os faça parar e se estabelecer num lugar. Nesse percurso pelo império do Mato Virgem, o herói passa diversas aventuras perigosas, com resultado positivo para o herói.

Uma dessas aventuras é o encontro do herói com o bacharel da Cananéia. Pela primeira vez, textualmente, o herói é reconhecido como um viajante. No diálogo, aparentemente fortuito, o bacharel chama o herói de ignoto viajor, viajante desconhecido, e utiliza uma linguagem arcaica misturada com galicismos, atestado da erudição do bacharel.

Em outra aventura, a perseguição empreendida por Boiúna Luna faz com que o herói e seus irmãos comecem uma fuga que termina com a perda do talismã dado pela "marvada" $\mathrm{Ci}$ - a muiraquitã. O episódio serve não só para consagrar o herói como um viajante desconhecido, um aventureiro, mas, principalmente para elaborar o motivo da segunda viagem - a busca incansável do herói pela muiraquitã.

Porém agora, cantava o lamento do uirapuru, nunca mais que Macunaíma havia de ser marupiara não, porque uma tracajá engulira a muiraquitã e o mariscador que apanhara a tartaruga tinha vendido a pedra verde pra um regatão peruano se chamando Venceslau Pietro Pietra. O dono do talismã enriquece- 
ra e parava fazendeiro e baludo lá em São Paulo, a cidade macota lambida pelo igarapé Tietê. (ANDRADE, 1988, p. 35)

Denominamos todo esse movimento de viagem de transformação, pois é aqui que as dimensões físicas, sociais, culturais do herói são redimensionadas, ganhando "status" de uma viagem especial, não somente pelo deslocamento espacial, mas também por um deslocamento imaginário e alegórico que compõe a totalidade do "brasileiro". Essa viagem constitui-se pela busca da muiraquitã, pelo banho mágico da transformação física e pela chegada e permanência em São Paulo.

Os preparos para a viagem têm peculiar importância, pois um dos movimentos é ir até a foz do Rio Negro e deixar a consciência na ilha de Marapatá. Isso implica, ao mesmo tempo, em salvaguardar a consciência indígena, sua cultura e língua, e também abrir um vazio, uma lacuna que pode ser preenchida por outras culturas, outra língua, outro ser.

Essa lacuna começa a ser preenchida no banho mágico da transformação: o herói ao banhar-se numa poça encantada transforma-se num homem louro, de olhos azuis e ninguém não seria capaz mais de indicar nele um filho da tribo retinta dos Tapanhumas. Jiguê só conseguiu lavar parte do corpo e ficou da cor do bronze, cor de jambo, como um tapuia, um caboclo. Maanape lava apenas as palmas das mãos e dos pés e fica como um negro. Estava formada, então, a tríade étnica que historicamente constitui a formação do povo brasileiro. Essa representação se opõe ao ideário romântico, onde a formação étnica do Brasil era constituída por brancos e índios, a exemplo dos romances indianistas de José de Alencar.

Até esse momento os movimentos de viagem ocorrem em espaços e tempos reconhecíveis, preenchidos por seres e entes sobrenaturais, pelas vivências indígenas, pela fauna e pela flora característicos das regiões Norte e Nordeste, enumerados caoticamente pelo texto, pois a configuração espacio-temporal da narrativa não estabelece qualquer vínculo realista, pelo contrário, é dominada pelo mito, pela invenção, pelo lendário. O herói está no seu local de origem, onde todos os elementos convivem numa harmonização existencial que lhes é própria.

A partir do banho da transformação, o rumo de São Paulo é estabelecido e a viagem toma um outro sentido. O olhar do ignoto viajante se depara com uma paisagem e uma cultura totalmente nova, desconhecida. Num primeiro momento, o herói começa explicar os fenômenos que vê tomando como referência o conhecido, o já visto. Ao chegarem em São Paulo, à noite, as luzes da cidade grande são compreendidas como estrelas numa visão característica de que ainda está preso às origens: "Todas as estrelas tinham descido do céu branco de tão molhado e garoa e banzavam pela cidade. Macunaíma lembrou de procurar Ci”. (ANDRADE, 1988, p. 39). 
A tecnologia progressista da cidade é um dos principais instrumentos de perturbação do conhecimento: as máquinas e objetos comuns na cidade também são traduzidos como elementos naturais da fauna e da flora - explicação própria do pensamento selvagem: analogia com seres e objetos conhecidos - . Para dominar essa nova cultura, Macunaíma pretende "brincar" com a Máquina. Foi assim que ele conquistou e dominou o império do Mato Virgem. As pretensões do herói são frustradas pela dessacralização do pensamento selvagem. Isso provocou uma perturbação profunda no espírito do herói. A impossibilidade de compreender a totalidade da matéria social que se apresentava, faz com o herói opte por simplificações criativas e imaginárias sobre as relações entre homens e máquinas.

O narrador adota quase sempre a focalização do herói, pois os elementos narrados são vistos a partir das vivências e linguagem do herói. A voz do narrador praticamente se anula diante da voz hegemônica do herói-viajante. Nesse sentido, podemos dizer que os elementos narrados são recebidos com estranheza e perplexidade, traduzidos por uma linguagem referencial do saber de Macunaíma, mas essa estranheza e perplexidade soam de forma natural em função de uma segunda tradução elaborada pelo narrador. O grau de estranheza e perplexidade é observada por alguns indícios doados pelo narrador: "A inteligência do herói está muito perturbada; O herói aprendendo calado. De vez em quando estremecia. Voltava a ficar imóvel escutando assuntando maquinando numa cisma assombrada. (ANDRADE, 1988, p. 40)

As doenças adquiridas com o contato com os filhos da mandioca sapinho, escarlatina, sarampão, erisipa e muita constipação - são outros exemplos concretos da estranheza, de um descompasso entre o pensamento do herói e a realidade presente. A transformação física, não foi acompanhada pela organização mental ou imunidade biológica; os filhos da mandioca, os homens brancos, melhor dizendo, as mulheres brancas são fáceis alvos para a sede sexual do herói, a peso de dinheiro, detalhe sem importância para ele, que não percebe o perigo que envolve tais relacionamentos: o sexo é aparentemente igual, mas os resultados causam dor e sofrimento físico.

Estava com a boca cheia de sapinhos por causa daquela primeira noite de amor paulistano. Gemia com as dores e não havia meios de sarar até que Maanape roubou uma chave de sacrário e deu pra Macunaíma chupar. O herói chupou chupou e sarou bem. Maanape era feiticeiro. (ANDRADE, 1988, p. 41).

O que mais percebemos desde a chegada do herói a São Paulo é a visão do mundo em transformação, onde o pensamento selvagem entra em processo de adaptação para que os objetivos traçados pelo roteiro de via- 
gem sejam atingidos. O conhecimento do herói transforma tudo: bichos, homens, objetos, etc; a única coisa que não sofre transformação é o gigante Piaimã, Venscelau Pietro Pietra, representante da figura do imigrante é o signo da pedra, do imutável, do inalterável, do permanente. O imigrante não é atingido pelo processo de transformação, não é adaptável pelo pensamento selvagem e por isso é o inimigo número um do herói.

Venscelau Pietro Pietra não tomou apenas o talismã do herói, mas também, redimensionando largamente o significado do signo, tomou também o lugar, a cultura, a consciência. Voltaremos a falar sobre o signo da pedra que é uma constante no imaginário do herói como representação de algo malévolo ao mundo.

A adaptação na cidade, aprender a língua, costumes, hábitos se justapõem sempre às imagens do pensamento selvagem, estabelecendo uma convivência pacífica, tanto no nível da linguagem, quanto no nível da ação do herói. A cada aventura do herói há a necessidade de retornar às origens, aos hábitos e costumes da tribo, ao pensamento selvagem, para restaurar a ordem, para re-equilibrar as forças que regem a composição do herói. Por outro lado, para conseguir atingir seus objetivos, o herói toma de empréstimo costumes e hábitos da civilização, como é o caso de sua transformação numa francesa para enganar o gigante Piaimã.

... virou Jiguê na máquina telefone e telefonou pra Venscelau Pietro Pietra que uma francesa queria falar com ele a respeito da máquina negócios. (...) Era tanta coisa que ficou pesado mas virou numa francesa tão linda que se defumou com jurema e alfinetou um raminho de pinhão paraguaio no patriotismo pra evitar quebranto. E foi no palácio de Venscelau Pietro Pietra. (ANDRADE, 1988, p. 48-49).

Na descrição do palácio do gigante Piaimã ocorre o segundo ponto de conjunção entre a ficção e a realidade, através de aproveitamentos recolhidos na viagem ao Norte do país, relatados em O Turista Aprendiz. A alcova do palácio do comedor de gente é decorada no centro com uma mesa de jacarandá esculpido arranjada com louça branco-encarnada de Breves e cerâmica de Belém.

Entre os movimentos de adaptação à cultura da civilização está a narração do capítulo Macumba. O herói sente-se muito contrariado por não ter conseguido vencer o gigante Piaimã e vale-se de um ritual religioso afro-brasileiro para conseguir atingi-lo. O olhar do herói constrói a representação do culto como um costume habitual dos civilizados. Na enumeração dos participantes a ficção invade a história, pois são citados nomes reconhecíveis historicamente nos meios intelectuais brasileiros, como Rui Barbosa que é transformado em ogã tocador de atabaque, um negrão filho de Ogum, que pelejava para acompanhar o ritmo novo, o canto livre. 
No nível do discurso, a figura de Rui Barbosa representa o passadismo cultural combatido pelos modernistas.

Macunaíma transforma-se no próprio Autor para acompanhar o cortejo dos Pândegos Modernistas: Jaime Ovalle, Dodô (Barroso do Amaral), o poeta Manu Bandeira, o artista suíço Blaise Cendrars, Ascenso Ferreira, Raul Bopp e Antonio Bento são os macumbeiros do canto livre. As inserções transpondo nomes de personalidades e atividades por elas exercidas preocupam-se em dar veracidade aos fatos. É importante observar nesse movimento que a preocupação com a credibilidade traduz-se em um dos topoi das narrativas de viagem, já estudado por Flora Süssekind (1990, p. 56).

O capítulo Carta pras Icamiabas talvez seja o mais representativo do processo de aculturação que o herói sofre no encontro com a civilização. Nesta missiva o herói relata às suas súditas aquilo que ele acredita ser a totalidade do mundo civilizado: a língua, as mulheres, a paisagem da cidade, os habitantes burgueses, a organização social. Para elaboração do relato o herói adota uma linguagem preciosista e arcaica, cheia de equívocos lingüísticos, o que revela sua falsa erudição.

É São Paulo construída sobre sete colinas, á feição tradicional de Roma, a cidade cesárea, "capita" da Latinidade de que provimos; e beija-lhe os pés a grácil e inquieta linfa do Tietê. As águas são magníficas, os ares tão amenos quanto os de Aquisgrana ou de Anverres, e a área tão a eles igual em salubridade e abundáncia, que bem se poderá afirmar, ao modo fino dos cronistas, que de três AAA se gera espontaneamente a fauna urbana. (ANDRADE, 1988, p. 80)

A adoção dessa linguagem representa muito mais do que uma aculturação com a aceitação fácil do vernáculo como a linguagem correta e mais apropriada aos ouvidos latinos do vosso imperador. É a expressão da forma e do discurso do projeto estético e ideológico dos modernistas. A forma se concretiza enquanto paródia da linguagem dos cronistas de viagem do nosso passado colonial, um resgate do passado para dessacralizálo enquanto referência cultural e orientador do pensamento sobre a nação. O discurso nacionalista mostra a realidade brasileira através do olhar do viajante aculturado, voz que se realiza através da homogeneidade cultural do indígena, do negro, do branco, numa concepção da formação do "brasileiro" como uma expressão cultural híbrida.

Como vedes, assaz hemos aproveitada esta demora na ilustre terra bandeirante, e si não descuidamos do nosso talismã, por certo que não poupàmos esforços nem vil metal, por aprendermos as coisas mais principais desta eviterna civilização latina, por que iniciemos, quando for do nosso retorno ao Mato Virgem, uma série de milhoramentos, que, muitos nos facilitarão a existência, e mais espalhem nossa prosápia de nação culta entre as mais cultas do Universo. (ANDRADE, 1988, p. 79). 
Ao mesmo tempo em que o "herói" configura-se pelo olhar como estrangeiro, a negatividade traduzida pela paródia e a falsa erudição da linguagem o colocam do lado de dentro, integrado àquela organização social, aceitando hábitos, importando técnicas e costumes.

Os procedimentos de inversão e comparação são uma constante em toda carta, mas principalmente na abordagem sobre as mulheres e seus costumes, considerando que a sensualidade e o sexo são a forma consagrada de relacionamento e idéia fixa do "herói". Esses procedimentos apresentam o olhar do estrangeiro - parodoxo na antinomia estrangeiro/ nativo - viajante de fora e de dentro, ambigüidade cuja tendência é se aprofundar, uma vez que a integração do nativo na civilização ocidental se dá a partir de regras impostas unilateralmente.

Como vós, senhoras Amazonas, tais damas formam um gineceu; estando os homens que em suas casas delas habitam, reduzidos escravos e condenados ao vil ofício de servirem. E por isso não se lhes chamam homens, sinão que á voz espúria de garçons respondem. (...) Porém si como vós, formam essas queridas senhoras um clã de mulheres, muito de vós se apartam no físico, no gênero de vida e nos ideais. (ANDRADE, 1988, p. 78).

Mas hei de saber, senhoras minhas, que por cá dia e noute divergem singularmente do vosso horário belígero; o dia começa quando para vós é o pino dele, e a noute, quando estais no quarto sono vosso, que, Poe derradeiro, é o mais reparador. (ANDRADE, 1988, p. 76).

O Thôma, procedimento comum da retórica da alteridade, curiosidades e maravilhas vistas pelo estrangeiro, sofre uma alteração de sentido: a paisagem de São Paulo é traduzida pela negatividade, mas numa linguagem que denota admiração pela novidade do fatos . Apesar de tudo, os paulistas vivem e prosperam na mais perfeita ordem e progresso. Aos paulistas-locomotivas só estão à altura os ingleses e os norte-americanos. $\mathrm{O}$ mesmo procedimento se repete quanto à originalidade da língua: falam numa língua e escrevem noutra.

Assim tão bem organizados vivem e prosperam os paulistas na mais perfeita ordem e progresso; e lhes não é escasso o tempo para construírem generosos hospitais, atraindo para cá todos os leprosos sulamaricanos, mineiros, paraibanos, peruanos, bolivianos, chilenos, paraguaios (...) animam as estradas do Estado e as ruas da capital, em garridas comitivas eqüestres ou em maratonas soberbas que são o orgulho de nossa raça desportiva, em cujo conspeito pulsa o sangue das heróicas bigas e quadrigas latinas! (ANDRADE, 1988, p. 82)

O tom empolgado com que o herói descreve os progressos de São Paulo contrasta com a descrição negativa sobre os leprosos, uma avaliação equivocada do que significa progresso e modernidade. A negatividade na 
tradução do que é visto, deslocam o olhar do estrangeiro, e o colocam do lado de dentro. Esse procedimento provoca uma sensação de não estar de todo, uma ambigüidade que não consegue se desfazer.

Entretanto, o que relativiza e até certo ponto resgata os atributos ruins do herói é o tratamento lúdico dado pelo narrador. Alguma coisa de visceralmente infantil cria em torno de Macunaíma uma aura de espontaneidade polimorfa que parece situá-lo num espaço aquém da consciência entendida como responsabilidade ou coesão moral. Mário de Andrade procurou manter-se, em geral, fiel ao modo de construção dos heróis da mitologia amazônica, acionados direta e prementemente pelos estímulos do prazer e do medo.

A dificuldade em definir a identidade simbólica do herói em termos de caráter brasileiro vem do cruzamento de perspectivas que enforma a rapsódia. Se, por um lado, o olhar sobre o civilizado, moderno e racional de um Mário de Andrade compõe uma figura que vale como sátira picante de todas as idealizações românticas do ethos nacional, por outro lado a flecha crítica também parte do olho primitivo, arcaico e mitopoético de outro Mário para atingir em cheio a cidade do progresso, os ridículos da burguesia paulista, com seus novos ricos e a sua cultura tida por grosseira e exibicionista. Para Macunaíma nem a cidade representa uma saída para a selva, nem a selva para a cidade. O sentido é de impasse e dor pelo impasse.

A Carta pras Icamiabas é o ponto alto da viagem, tanto do personagem-viajante, quanto do projeto marioandradino de desrealização dos relatos de viagem. O humor paródico é o instrumento escolhido para concretizar as imagens dessacralizadoras de vários temas colocados na ordem do dia pelos modernistas: estrangeiro $\mathrm{x}$ nativo, primitivo $\mathrm{x}$ civilizado, modernidade $\mathrm{x}$ atraso.

O herói Macunaíma é o elemento catalisador dessas dissonâncias, desses descompassos que permeiam a visão do "brasileiro" de Mário de Andrade. A desqualificação do herói na análise de sua condição enquanto elemento aculturado pelo elemento estrangeiro, a sua pseudo-erudição como elemento de conservação do status quo causam estranheza e desconforto, uma vez que o processo de aculturação não auxilia o herói em atingir o objetivo da viagem.

Esse paradoxo vivido pelo ignoto viajante é o mesmo paradoxo enfrentado pelo turista aprendiz Mário de Andrade. A estranheza e o desconforto do estrangeiro em terra alheia promove a necessidade de adaptação à cultura do lócus-presente. O percurso inverso das viagens empreendidas por ambos, estabelece paralelismos e correlações que diminuem os contrastes e aproximam os viajantes através dos procedimentos lingüísticos no encontro com o Outro. 


\section{A viagem às origens}

O terceiro movimento inicia sem que o objetivo principal do personagem-viajante se concretize. Este movimento é de suma importância por apresentar o choque cultural entre a selva e a ciadade, entre o pensamento selvagem e o racionalismo. Os impasses se acutizam e parece não haver saída para o herói. É a figura do des-locado que se manifesta com toda força. O olhar do viajante passa a se fixar nas mazelas e malefícios da vida urbana, da civilização ocidental e o faz lembrar de suas origens.

Enquanto o "herói" esperava uma oportunidade para reaver a muiraquitã, adaptava-se à vida urbana, aos costumes e à língua dos "civilizados". Mas a espera foi longa, e então, começaram os problemas: quase é linchado, quase é preso; perdeu a aposta para o Chuvisco, é perseguido pela velha Ceiuci, adoece sempre, tem delírios, não consegue ir para Europa como pintor, é enganado e roubado pelo mascate, é enganado pelo macaco e quase morre. Todos esses contratempos e sofrimentos do herói geram uma revolta e um discurso inflamado que projetam bem a ideologia da rapsódia.

Paciência, manos! Não! Não vou na Europa não. Sou americano e meu lugar é na América. A civilização européia decerto esculhamba a inteireza do nosso caráter. (ANDRADE 1988, p. 114-115)

O ápice do des-locamento é o malogro do transatlântico que o levaria para uma viagem por mar, para a Europa. Agora a segurança do herói estava no valente Jiguê e no feiticeiro Maanape, que representam uma referência concreta de suas origens. A necessidade de retornar às origens e resgatar sua consciência acelera as investidas contra o inimigo número um - Venscelau Pietro Pietra.

Esta é a deixa para a viagem de volta. A morte do imigrante, comedor de gente - inversão da cultura canibal de tribos indígenas brasileiras - projeta uma viagem certa, mas um futuro incerto, vazio. Macunaíma está feliz por voltar e reencontrar o seu lugar, ao mesmo tempo que sente saudade das aventuras pela urbe.

No percurso de volta, o "herói" reencontra seu mundo, outros mundos, outros seres (frade, inventor, princesa chique / Iriqui, Mapinguari, Oibê). Os seres e os elementos do mundo original vão se transformando, desaparecendo, dando lugar a outros seres e elementos. Macunaíma fica só, melancólico, deslocado. Voltou para pegar a consciência que deixara na ilha de Marapatá, não a encontrou e tomou a consciência de um latinoamericano. Aqui, tomamos consciência do inevitável deslocamento existencial e cultural do herói. 
A perda de suas referências, até o séquito o abandona, até o papagaio-aprendiz desaparece, faz o herói desistir da vida - Não vim no mundo para ser pedra - e ir viver no céu - transformar-se na Ursa Maior.

A viagem de volta percorre o mesmo roteiro da viagem de vinda, entretanto tudo está diferente, tudo está mudado. Na verdade, o que realmente muda é o olhar do herói, é a consciência de que aquele lugar não é mais o seu. Macunaíma é o brasileiro desavindo consigo mesmo. Não encontrando lugar próprio nem na metrópole, nem no Uraricoera, nem na Paulicéia, ele padece em ambos.

A opção em desistir da vida, em não ser pedra apresenta uma característica, agora, constante do herói. O subtítulo da obra - o herói sem nenhum caráter - aponta para a composição de um ser entre humano e mítico, que desempenha certos papéis e vai em busca de um bem essencial. Apresenta, também, o brasileiro à procura de uma identidade que, de tão plural que é, beira a surpresa e a indeterminação. A crítica invariavelmente analisa a figura do herói da nossa gente a partir da sua inconstância, instabilidade, volubilidade. No entanto, a consciência dessa vicissitude, faz com que o herói opte em não ser algo, para ser outro - Ursa Maior. Sendo volúvel e instável, concretiza-se em ser.

A oposição entre o signo da pedra - representada pela figura do gigante Piaimã, comedor de gente - e da estrela, representação espectral da transformação da vida em morte instaura um tom pessimista à narrativa, onde as alternativas colocam-se como negativas. A pedra por ser uma força malévola trazida pela civilização ocidental; as estrelas por serem um "brilho inútil".

A viagem final de Macunaíma é alegórica, mas conclusiva. É a resolução do impasse criado pelo encontro entre a selva e a cidade, entre o primitivo e a modernidade, entre o índio e o branco. Não foi uma solução digna de um herói, mas a diversidade, a pluralidade cultural na constatação do conceito de "brasileiro" impedem qualquer solução que não seja a total aceitação dessa heterogeneidade. A constatação da diferença do Outro no mesmo, o olhar perplexo de se ver através do Outro deixa irresolvida a tensão fundadora. Coexistem ou alternam-se, na gangorra ideológica, o otimismo e o pessimismo em face do destino do povo brasileiro.

O caráter de perplexidade que envolve a impossibilidade de definições, classificações e descrições precisas do que é o Brasil, a inelutável impotência em dar voz a todos os brasileiros e abarcar a totalidade do conceito de brasilidade permeiam os discursos tanto do narrador de Macunaíma, que muitas vezes se confunde com o próprio escritor e se justapõe ao personagem-viajante Macunaíma, quanto do escritor-viajante Mário de Andrade em O Turista Aprendiz. Ambos partem em busca do 
talismã que representa sua identidade cultural. Ambos são surpreendidos pela diferença. Ambos alteram o roteiro de sua viagem existencial.

As narrativas de viagem atestam: o encontro com a alteridade gera sempre fraturas. Mário de Andrade perseguiu essas fraturas de duas formas: como ficcionista e como cronista de viagem. O ponto de partida foi sempre o mesmo: encontrar uma definição para os conceitos de brasilidade e identidade nacional.

\section{BIBLIOGRAFIA}

ANDERSON, Benedict. Nações e consciência nacional. Rio de Janeiro, Ática, 1989.

ANDRADE, Mário de. Macunaíma. O herói sem nenhum caráter. Edição Crítica. Coord. Telê Porto Ancona Lopez. Paris, Association Archives de la Litterature latino-americaine, dês Caraïbes et africaine du XX siécle; Brasília, DF, CNPq, 1988.

ANDRADE, Mário. O Turista Aprendiz. 2 ed. Introd. e Notas de Telê Porto Ancona Lopez. São Paulo, Duas Cidades, 1983.

ANDRADE, Carlos Drummond. A lição do amigo. Cartas de Mário de Andrade a Carlos Drummond de Andrade. Ed. anotada pelo destinatário. Rio de Janeiro, José Olympio, 1982.

BANDEIRA, Manuel. Cartas de Mário de Andrade a Manuel Bandeira. Rio de Janeiro, Org. Simões Ed., 1958.

HARTOG, François. Uma retórica da alteridade. In: O espelho de Heródoto. Ensaios sobre a representação do outro. Trad. Jacyntho Lins Brandão. Belo Horizonte, Ed. UFMG, 1999.

HOBSBOWM, Eric. Nações e nacionalismo desde 1780: programa, mito e realidade. Rio de Janeiro, Paz e Terra, 1991.

LOPEZ, Telê Porto Ancona. A bordo do diário. Introdução a ANDRADE, Mário. O turista aprendiz. 2 ed. São Paulo, Duas Cidades, 1983.

MAYA, Ivone S. Ramos. Anti-viajante que sou: o conceito de viagem na obra de Mário de Andrade. IPOTESI. Revista de Estudos Literários. Juiz de Fora, UFJF, v.3, n. $1-1^{\circ}$. Semestre, 1999. 
PROENÇA, M. Cavalcanti. Roteiro de Macunaíma. Rio de Janeiro, Civilização Brasileira, 1969.

SÜSSEKIND, Flora. O Brasil não é longe daqui. O narrador, a viagem. São Paulo, Companhia das Letras, 1990.

SCHWARZ, Roberto. A importação do romance e suas contradições em Alencar. In: Ao vencedor as batatas. 3 ed. São Paulo, Duas Cidades, 1988.

VERNANT, Jean-Pierre. Mito e Tragédia na Grécia Antiga. Trad. Ma. Da Conceição et alii. São Paulo, Brasiliense, 1988. 